\title{
Oribatid mites (Acari, Oribatida) and their seasonal dynamics in a floating bog mat in Jeziorka Kozie Reserve, Tuchola Forest (Poland)
}

\author{
ANNA SENICZAK \\ Department of Ecology, University of Technology and Life Sciences, Kordeckiego 20, \\ 85-225 Bydgoszcz, Poland, aseniczak@utp.edu.pl
}

(Received on 31 January 2008; Accepted on 5 January 2011)

\begin{abstract}
The oribatid mite community from the edge of the Sphagnum mat of dystrophic K1 pond (Jeziorka Kozie Reserve, Poland), and its seasonal dynamics was studied in 2006 (29 May, 6 August and 22 October). In all seasons, Limnozetes foveolatus dominated, followed by L. ciliatus; abundant were also L. lustrum, Trhypochthoniellus longisetus, Trhypochthonius nigricans, and Trimalaconothrus foveolatus. In autumn, the mean density of Oribatida was significantly higher than in spring. The percentage of juvenile stages was generally low, but highest in summer $(22 \%)$, while in the other seasons it was about half as high. Metabelba sphagni is new to the Polish fauna.
\end{abstract}

Keywords: seasonal dynamics, Acari, Oribatida, bog, Sphagnum, dystrophic pond, floating bog mat

\section{INTRODUCTION}

Bog ecosystems have been well studied by botanists but received only little attention from animal ecologists (BelANGER 1976). Mites from bogs are also poorly known, although they are usually the most abundant and diverse group of invertebrates in this habitat (Popp 1962; Belanger 1976) and play an important role as decomposers (KURIKI 2008).

The aquatic Oribatida encompass only a small percentage of all oribatid species (less than 1\%) but their abundance can be very high (RAJSKI 1961; KURIKI 2008; Schatz \& Behan-Pelletier 2008). For example, at the edge of the Sphagnum mat of Lake Martwe in the Tuchola Forest in northwestern Poland, the density of Oribatida was 165000 ind. $/ \mathrm{m}^{2}$ (SeniczaK et al. 2006b). This is in agreement with Peus (1932), who concluded that mires, particularly Sphagnum mats, are optimum biotopes for oribatid mites.

The seasonal dynamics of Oribatida has been studied for a whole year, in 2-month intervals, in a fen in southern Lithuania (EITMINAVIČIŪTĖ 1966) and for shorter periods 
in raised bogs in the U.S.A. (Belanger 1976; Donaldson 1996). KURIKI (1993, 1995, 1996) studied in a mire at Yachidaira, Northeast Japan, the life cycle of Trhypochthoniellus brevisetus Kuriki, 2005 (as Trhypochthoniellus setosus Willmann, 1928), the dominant species, and also of Limnozetes ciliatus (Schrank, 1803) (KURIKI 2008).

The aim of this research was to study some parameters of the oribatid mite community of the Sphagnum mat of a dystrophic pond, its seasonal dynamics, and some parameters of species.

\section{Study area}

The study site is located in Jeziorka Kozie Reserve (Tuchola Forest, northwestern Poland). The reserve has an area of 12.3 ha and protects 3 dystrophic ponds. The mean annual precipitation is $500-600 \mathrm{~mm}$, mean annual temperature is $7.5-8^{\circ} \mathrm{C}$, mean temperature of January ranges from -2 to $-3^{\circ} \mathrm{C}$, while mean temperature of July, from 18 to $19^{\circ} \mathrm{C}$. The growing period lasts $210-220$ days. It starts on average in early April and ends in early November (BoIŃSKI \& BorŃSKA 2003).

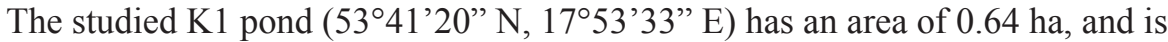
located at $119 \mathrm{~m}$ a. s. 1. It is surrounded by pine-birch forest, in which Scots pine ( $\mathrm{Pi}$ nus sylvestris L.) dominates, and silver birch (Betula pendula Roth) is less abundant. Water of the pond is acidic ( $\mathrm{pH}$ 5.0), and a floating Sphagnum-dominated mat partly covers its surface.

The sampling site was the plant community Rhynchosporetum albae. In total 8 species were found there, with dominant white beak-sedge Rhynchospora alba (L.) Vahl and flat-topped bog-moss Sphagnum fallax (Klinggr.) Klinggr. Relatively abundant was common cotton grass (Eriophorum angustifolium Honck., straw-coloured water moss Calliergon stramineum (Brid.) Kindb. and common cranberry Vaccinium oxycoccos L. Less abundant were: marsh cinquefoil Comarum palustre L., common sundew Drosera rotundifolia L. and milk-parsley Peucedanum palustre (L.) Moench (Boiński \& Boińska 2003).

\section{MATERIAL AND METHODS}

Samples were taken in spring (29 May), summer (6 August), and autumn (22 October) of 2006. In each season, 10 samples of Sphagnum fallax, each $10 \mathrm{~cm} \times 10 \mathrm{~cm}$ and $5 \mathrm{~cm}$ deep, were taken from the edge of the Sphagnum mat. The mites were extracted using a modified Tullgren funnel, and Oribatida were identified to species, including the juvenile stages. The names of species follow Weigmann (2006) and partly SubíAs (2004). Population of each species was characterized with the indices of abundance $\left(A=\right.$ number of mites of this species per $\left.\mathrm{m}^{2}\right)$, dominance $(D=\%$ of the total number of oribatid mites) and constancy ( $C=\%$ of samples with this species). The oribatid mite community was characterized by the number of species and Shannon index of diversity (Hs) (ODum 1982). For statistical analyses, the values were ln-transformed (ŁOMNICKi 2010) and analyzed with the Kruskal-Wallis test, followed by the Mann-Whitney U test. The statistical calculations were carried out with STATISTICA 6 software. 


\section{RESULTS}

In total, 60782 mites were extracted, including 60316 of Oribatida. The mean density of mites increased significantly from spring to autumn (Table 1). In all seasons, the dominant oribatid species was Limnozetes foveolatus Willmann, 1939, followed by L. ciliatus (Schrank, 1803); relatively abundant was also L. lustrum BehanPelletier, 1989, while L. rugosus (Sellnick, 1923) was infrequent (Table 2). High densities were reached also by members of Malaconothroidea: Trhypochthoniellus longisetus (Berlese, 1904), Trhypochthonius nigricans Willmann, 1928 and Trimalaconothrus foveolatus Willmann, 1931. In spring relatively abundant was Hydrozetes longisetosus S. Seniczak \& A. Seniczak, 2009 and in summer, Pilogalumna tenuiclava (Berlese, 1908) and Oppiella nova (Oudemans, 1902).

Table 1. Abundance (in $10^{3}$ ind. $/ \mathrm{m}^{2}$ ) and species diversity of mites in a floating bog mat in various seasons. SD = standard deviation. Superscripts denote significant differences between spring and summer $\left({ }^{\mathrm{a}}\right)$, spring and autumn $\left({ }^{\mathrm{b}}\right)$ and summer and autumn $\left({ }^{\mathrm{c}}\right)$ at $P \leq 0.05$

\begin{tabular}{lccc}
\hline Index & Spring & Summer & Autumn \\
\hline Oribatida abundance mean & 153.58 & 170.01 & $280.89^{\mathrm{b}}$ \\
Oribatida abundance range & $36.80-392.50$ & $54.10-310.00$ & $38.70-552.60$ \\
Oribatida abundance SD & 103.07 & 83.82 & 158.56 \\
\% of juveniles among Oribatida & 13.42 & 21.72 & 12.83 \\
Acari abundance mean & 154.58 & 172.20 & $282.36^{\mathrm{b}}$ \\
Acari abundance range & $37.10-393.80$ & $55.00-316.90$ & $39.10-553.60$ \\
Acari abundance SD & 103.28 & 84.97 & 158.43 \\
Number of species of Oribatida & 29 & 27 & 30 \\
Shannon index of diversity $(H \mathrm{~s})$ & 1.36 & 1.66 & 1.23 \\
\hline
\end{tabular}

In total, 36 oribatid species were recorded, of which $50 \%$ were represented in samples both by adults and juveniles (Table 3), 16 species only by adults, whereas Nothrus palustris C. L. Koch, 1839 and Scheloribates laevigatus (C. L. Koch, 1836) only by juveniles. In the age structure of some species (genera Hydrozetes and Limnozetes, and Oppiella nova), adults predominated, while in others (Trhypochthonius nigricans, Trimalaconothrus foveolatus, T. maior) the juvenile stages were more abundant, irrespective of the season (Table 3). The highest percentage of extracted juvenile stages $(22 \%)$ was recorded in summer, while in the other seasons it was about half as high.

Adults and juveniles of some species (Hydrozetes longisetosus, H. octosetosus Willmann, 1932, Limnozetes rugosus, Punctoribates sellnicki Willmann, 1928) achieved higher densities in spring than in other seasons, others (Limnozetes lustrum, Mainothrus badius (Berlese, 1905), Nanhermannia cf. coronata Berlese, 1913 and 


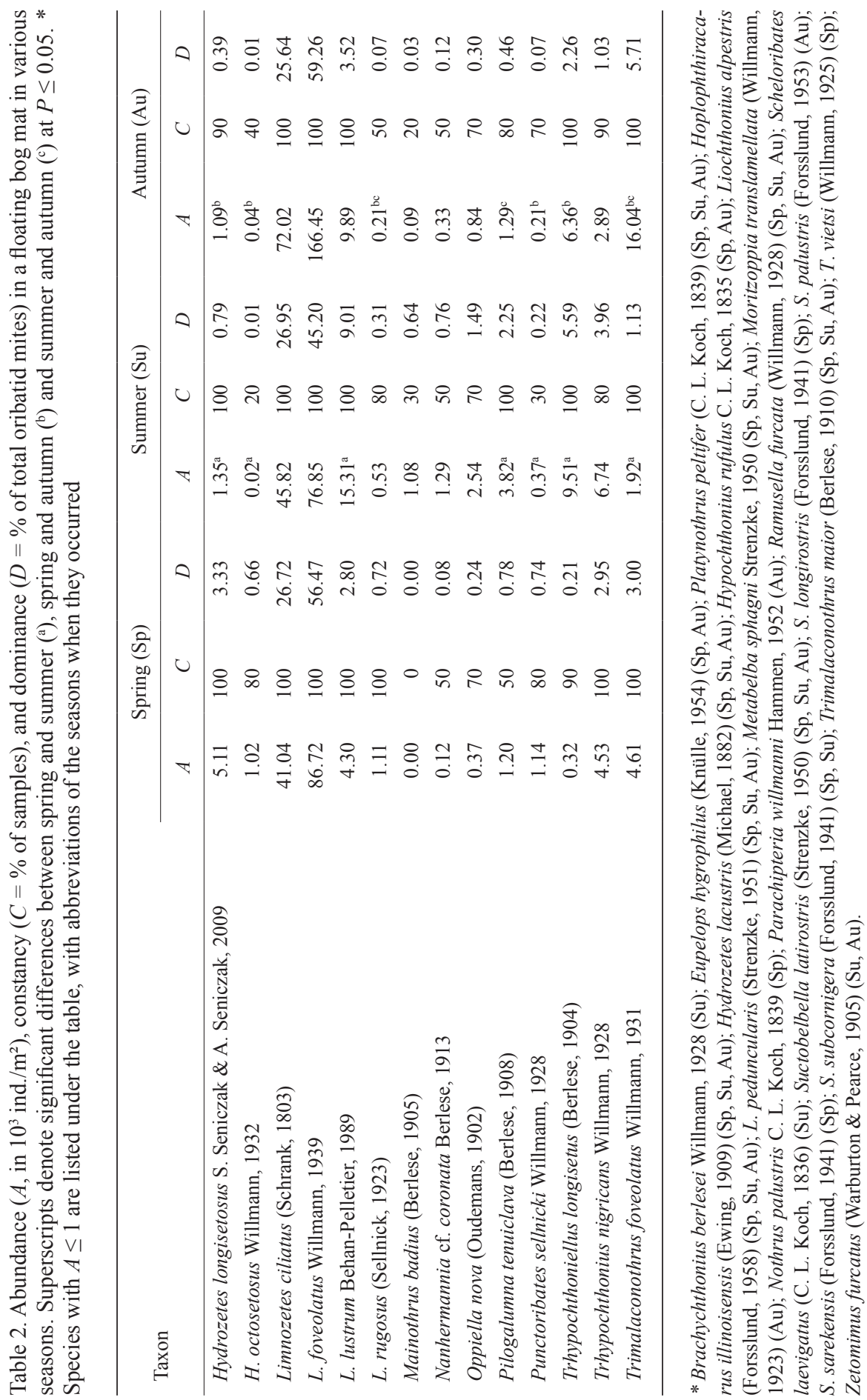


Table 3. Seasonal mean abundance $\left(A\right.$, in $10^{3}$ ind. $\left.\mathrm{m}^{2}\right)$ and percentage of adults (ad) and juveniles (juv) of Oribatida in a floating bog mat. * Species with $A \leq 1$ are listed under the table. $\mathrm{SD}=$ standard deviation. Superscripts denote significant differences between spring and summer ${ }^{\mathrm{a}}$ ), spring and autumn $\left({ }^{b}\right)$ and summer and autumn $\left({ }^{c}\right)$ at $P \leq 0.05$

\begin{tabular}{|c|c|c|c|c|c|c|c|}
\hline \multirow[b]{2}{*}{ Species } & & \multicolumn{2}{|l|}{ Spring } & \multicolumn{2}{|l|}{ Summer } & \multicolumn{2}{|l|}{ Autumn } \\
\hline & & $\begin{array}{c}A-\operatorname{mean} \pm \mathrm{SD} \\
\text { range }\end{array}$ & $\%$ & $A-\underset{\text { range }}{\operatorname{mean} \pm \mathrm{SD}}$ & $\%$ & $A-\underset{\text { range }}{\operatorname{mean} \pm \mathrm{SD}}$ & $\%$ \\
\hline \multirow[t]{2}{*}{$\begin{array}{l}\text { Hydrozetes } \\
\text { longisetosus }\end{array}$} & $\mathrm{ad}$ & $\begin{array}{c}2.72 \pm 1.14 \\
1.1-5.4\end{array}$ & 53.2 & $\begin{array}{c}1.25^{\mathrm{a}} \pm 1.44 \\
0.0-4.7\end{array}$ & 92.6 & $\begin{array}{c}0.99^{\mathrm{b}} \pm 1.24 \\
0.0-3.6\end{array}$ & 90.8 \\
\hline & juv & $\begin{array}{c}2.39 \pm 3.87 \\
0.0-12.1\end{array}$ & 46.8 & $\begin{array}{c}0.10 \pm 0.15 \\
0.0-0.4\end{array}$ & 7.4 & $\begin{array}{c}0.1 \pm 0.09 \\
0.0-0.3\end{array}$ & 9.2 \\
\hline \multirow[t]{2}{*}{ H. octosetosus } & $\mathrm{ad}$ & $\begin{array}{c}0.69 \pm 1.53 \\
0.0-5.0\end{array}$ & 67.6 & $0.00^{\mathrm{a}}$ & 0.0 & $\begin{array}{c}0.01^{\mathrm{b}} \pm 0.03 \\
0.0-0.1\end{array}$ & 25.0 \\
\hline & juv & $\begin{array}{c}0.33 \pm 0.77 \\
0.0-2.5\end{array}$ & 32.3 & 0.00 & 0.0 & $\begin{array}{c}0.03 \pm 0.05 \\
0.0-0.1\end{array}$ & 75.0 \\
\hline \multirow[t]{2}{*}{ Limnozetes ciliatus } & $\mathrm{ad}$ & $\begin{array}{c}36.35 \pm 26.70 \\
15.9-105.3\end{array}$ & 88.6 & $\begin{array}{c}38.44 \pm 22.33 \\
4.7-7.8\end{array}$ & 83.9 & $\begin{array}{c}60.03 \pm 46.96 \\
10.4-145.7\end{array}$ & 83.3 \\
\hline & juv & $\begin{array}{c}4.69 \pm 4.86 \\
0.3-16.3\end{array}$ & 11.4 & $\begin{array}{c}7.38 \pm 5.49 \\
0.1-15.8\end{array}$ & 16.1 & $\begin{array}{c}11.99 \pm 10.53 \\
1.6-36.8\end{array}$ & 16.6 \\
\hline \multirow[t]{2}{*}{ L. foveolatus } & $\mathrm{ad}$ & $\begin{array}{c}82.51 \pm 78.01 \\
5.7-280.9\end{array}$ & 95.1 & $\begin{array}{c}71.12 \pm 48.31 \\
13.4-136.2\end{array}$ & 92.5 & $\begin{array}{c}163.58 \pm 129.64 \\
4.3-387.7\end{array}$ & 98.3 \\
\hline & juv & $\begin{array}{c}4.21 \pm 5.24 \\
0.0-17.1\end{array}$ & 4.8 & $\begin{array}{c}5.73 \pm 5.12 \\
0.0-16.0\end{array}$ & 7.5 & $\begin{array}{c}2.87 \pm 2.06 \\
0.2-6.5\end{array}$ & 1.7 \\
\hline \multirow[t]{2}{*}{ L. lustrum } & $\mathrm{ad}$ & $\begin{array}{c}4.15 \pm 2.97 \\
0.3-9.6\end{array}$ & 96.5 & $\begin{array}{c}12.29 \pm 8.23 \\
0.5-26.9\end{array}$ & 80.3 & $\begin{array}{c}8.45 \pm 7.78 \\
1.0-25.8\end{array}$ & 85.4 \\
\hline & juv & $\begin{array}{c}0.15 \pm 0.24 \\
0.0-0.6\end{array}$ & 3.5 & $\begin{array}{c}3.02^{\mathrm{a}} \pm 2.85 \\
0.0-9.5\end{array}$ & 19.7 & $\begin{array}{c}1.44^{\mathrm{b}} \pm 1.13 \\
0.0-3.3\end{array}$ & 14.6 \\
\hline \multirow[t]{2}{*}{ L. rugosus } & $\mathrm{ad}$ & $\begin{array}{c}1.02 \pm 0.83 \\
0.2-2.8\end{array}$ & 91.9 & $\begin{array}{c}0.52 \pm 0.41 \\
0.0-1.3\end{array}$ & 98.1 & $\begin{array}{c}0.18^{\mathrm{b}} \pm 0.26 \\
0.0-0.8\end{array}$ & 85.7 \\
\hline & juv & $\begin{array}{c}0.09 \pm 0.22 \\
0.0-0.7\end{array}$ & 8.1 & $\begin{array}{c}0.01 \pm 0.03 \\
0.0-0.1\end{array}$ & 1.9 & $\begin{array}{c}0.03 \pm 0.05 \\
0.0-0.1\end{array}$ & 14.3 \\
\hline \multirow[t]{2}{*}{ Mainothrus badius } & $\mathrm{ad}$ & 0.00 & 0.0 & $\begin{array}{c}0.31 \pm 0.95 \\
0.0-3.0\end{array}$ & 28.7 & $\begin{array}{c}0.06 \pm 0.20 \\
0.0-0.6\end{array}$ & 66.7 \\
\hline & juv & 0.00 & 0.0 & $\begin{array}{c}0.77 \pm 2.40 \\
0.0-7.6\end{array}$ & 71.3 & $\begin{array}{c}0.03 \pm 0.07 \\
0.0-0.2\end{array}$ & 33.3 \\
\hline \multirow[t]{2}{*}{$\begin{array}{l}\text { Nanhermannia } \text { cf. } \\
\text { coronata }\end{array}$} & $\mathrm{ad}$ & $\begin{array}{c}0.05 \pm 0.07 \\
0.0-0.2\end{array}$ & 41.7 & $\begin{array}{c}0.87 \pm 1.53 \\
0.0-4.4\end{array}$ & 67.4 & $\begin{array}{c}0.23 \pm 0.50 \\
0.0-1.6\end{array}$ & 69.7 \\
\hline & juv & $\begin{array}{c}0.07 \pm 0.16 \\
0.0-0.5\end{array}$ & 58.3 & $\begin{array}{c}0.42 \pm 0.77 \\
0.0-2.2\end{array}$ & 32.6 & $\begin{array}{c}0.10 \pm 0.17 \\
0.0-0.5\end{array}$ & 30.3 \\
\hline \multirow[t]{2}{*}{$\begin{array}{l}\text { Pilogalumna } \\
\text { tenuiclava }\end{array}$} & ad & $\begin{array}{c}0.34 \pm 0.51 \\
0.0-1.5\end{array}$ & 28.3 & $\begin{array}{c}1.65^{\mathrm{a}} \pm 1.69 \\
0.0-5.0\end{array}$ & 43.2 & $\begin{array}{c}0.75 \pm 1.04 \\
0.0-3.4\end{array}$ & 58.1 \\
\hline & juv & $\begin{array}{c}0.86 \pm 1.18 \\
0.0-3.6\end{array}$ & 71.7 & $\begin{array}{c}2.17 \pm 1.90 \\
0.0-5.7\end{array}$ & 56.8 & $\begin{array}{c}0.54^{\mathrm{c}} \pm 0.57 \\
0.0-1.7\end{array}$ & 41.9 \\
\hline \multirow[t]{2}{*}{$\begin{array}{l}\text { Punctoribates } \\
\text { sellnicki }\end{array}$} & $\mathrm{ad}$ & $\begin{array}{c}0.38 \pm 0.38 \\
0.0-1.1\end{array}$ & 33.3 & $\begin{array}{c}0.23 \pm 0.57 \\
0.0-1.8\end{array}$ & 62.2 & $\begin{array}{c}0.21 \pm 0.21 \\
0.0-0.6\end{array}$ & 100.0 \\
\hline & juv & $\begin{array}{c}0.76 \pm 0.58 \\
0.0-1.6\end{array}$ & 66.7 & $\begin{array}{c}0.14^{\mathrm{a}} \pm 0.29 \\
0.0-0.9\end{array}$ & 37.8 & $0.00^{\mathrm{b}}$ & 0.0 \\
\hline
\end{tabular}




\begin{tabular}{|c|c|c|c|c|c|c|c|}
\hline \multirow[t]{2}{*}{$\begin{array}{l}\text { Trhypochthoniellus } \\
\text { longisetus }\end{array}$} & $\mathrm{ad}$ & $\begin{array}{c}0.12 \pm 0.15 \\
0.0-0.5\end{array}$ & 37.5 & $\begin{array}{c}0.73^{\mathrm{a}} \pm 0.99 \\
0.0-2.8\end{array}$ & 7.7 & $\begin{array}{c}3.94^{\mathrm{bc}} \pm 3.51 \\
0.1-11.3\end{array}$ & 61.9 \\
\hline & juv & $\begin{array}{c}0.20 \pm 0.33 \\
0.0-1.1\end{array}$ & 62.5 & $\begin{array}{c}8.78^{\mathrm{a}} \pm 6.56 \\
0.3-19.1\end{array}$ & 92.3 & $\begin{array}{c}2.42^{\mathrm{b}} \pm 3.47 \\
0.0-11.7\end{array}$ & 38.0 \\
\hline \multirow[t]{2}{*}{$\begin{array}{l}\text { Trhypochthonius } \\
\text { nigricans }\end{array}$} & $\mathrm{ad}$ & $\begin{array}{c}1.68 \pm 1.10 \\
0.5-4.0\end{array}$ & 37.1 & $\begin{array}{c}0.43^{\mathrm{a}} \pm 0.74 \\
0.0-2.4\end{array}$ & 6.4 & $\begin{array}{c}0.51^{\mathrm{b}} \pm 0.51 \\
0.0-1.4\end{array}$ & 17.6 \\
\hline & juv & $\begin{array}{c}2.85 \pm 3.36 \\
0.5-11.7\end{array}$ & 62.9 & $\begin{array}{c}6.31 \pm 8.29 \\
0.0-23.0\end{array}$ & 93.6 & $\begin{array}{c}2.38 \pm 2.20 \\
0.0-7.1\end{array}$ & 82.3 \\
\hline \multirow[t]{2}{*}{$\begin{array}{l}\text { Trimalaconothrus } \\
\text { foveolatus }\end{array}$} & $\mathrm{ad}$ & $\begin{array}{c}1.11 \pm 0.72 \\
0.1-1.9\end{array}$ & 24.1 & $\begin{array}{c}0.22^{\mathrm{a}} \pm 0.30 \\
0.0-0.9\end{array}$ & 11.5 & $\begin{array}{c}2.87^{\mathrm{bc}} \pm 1.80 \\
0.3-5.7\end{array}$ & 17.9 \\
\hline & juv & $\begin{array}{c}3.50 \pm 1.84 \\
1.5-6.9\end{array}$ & 75.9 & $\begin{array}{c}1.70 \pm 0.96 \\
0.2-3.0\end{array}$ & 88.5 & $\begin{array}{c}13.17^{\mathrm{bc}} \pm 8.87 \\
4.0-31.9\end{array}$ & 82.1 \\
\hline
\end{tabular}

* Platynothrus peltifer, Hydrozetes lacustris, Hypochthonius rufulus, Oppiella nova, Trimalaconothrus maior

Pilogalumna tenuiclava) were most abundant in summer, and others yet (Limnozetes ciliatus and Trimalaconothrus foveolatus), in autumn. In some species adults and juveniles achieved highest abundance in different seasons; for example juveniles of Limnozetes foveolatus, Trhypochthoniellus longisetus and Trhypochthonius nigricans were most abundant in summer, while adults of two former species were most abundant in autumn and of T. nigricans, in spring.

Interestingly, the juveniles of some closely related species reached their maximum densities in different seasons. For example juveniles of Limnozetes foveolatus and L. lustrum were most abundant in summer, those of L. ciliatus in autumn, and L. rugosus, in spring. Some members of Malaconothroidea (Trhypochthoniellus longisetus and Trhypochthonius nigricans) were the most abundant in summer, Trimalaconothrus maior in spring, while T.foveolatus, in autumn. Based on the species list of Olszanowski et al. (1996) and NiedbaŁa \& Olszanowski (2008), Metabelba sphagni Strenzke, 1950 is new to the Polish fauna.

\section{DISCUSSION}

Three major environmental factors are a challenge for plants and animals in bogs: (1) waterlogged substrate; (2) low level of nutrients; and (3) fluctuations of temperature and moisture content (BELANGER 1976). The extreme habitats, either very wet or dry, are suitable for only few species, which occur there in high numbers (TARras-Wahlberg 1961; Belanger 1976; BorCard 1997). The edge of the Sphagnum mat is a very wet habitat, where the species diversity of Oribatida is rather low, while their abundance is high (RAJSki 1961; Donaldson 1996; SEniczak et al. 2006a, b). This is confirmed by this study.

The most abundant species, Limnozetes foveolatus, was also abundant (as $L$. palmerae Behan-Pelletier, 1989) in North American bogs (DonALdson 1996) and at Lake Martwe in Tuchola Forest, Poland, where it made up 64\% of all Oribatida (SENICZAK et al. 2006b). Limnozetes foveolatus is the smallest species of the genus Limnozetes, with the body length range of 266-292 $\mu$ m (BeHAN-Pelletier 1989; 
SeniczaK \& Seniczak 2009). Donaldson (1996) concluded that the small body size might be an advantage for an oribatid mite, which can then find more habitable spaces to feed or avoid predators (WALTER \& NORTON 1984). The second most abundant was L. ciliatus, like in the studies of Donaldson (1996) and SenICZAK et al. (2006b). At Lake Martwe in the Tuchola Forest, only 2 species from the genus Limnozetes were found (Seniczak et al. 2006b), while in this study 4 species were recorded. Coexistence of several species from the same genus indicates a more advanced stage of succession (SKUBAŁa 2004).

Relatively abundant were also Trhypochthoniellus longisetus, Trhypochthonius nigricans and Trimalaconothrus foveolatus. KeHL (1997) studied in detail the ecology of Malaconothroidea from bogs, and found that some species, including Trhypochthoniellus longisetus and Trhypochthonius nigricans, were restricted to floating Sphagnum mats, with very wet and oligotrophic conditions. Trimalaconothrus foveolatus was among the species well adapted to wet and oligotrophic conditions, but with wider ecological tolerance.

Most studies on bogs have shown that Oribatida were most abundant in autumn or early winter, and this was also confirmed in this study. EITMINAVIČIŪTĖ (1966) found that seasonal dynamics of Oribatida varied in the biotopes situated at various distances from open water in a fen in southern Lithuania. Oribatid mites more distant from open water were the most abundant in June, while at the water's edge, in December (EITMINAVIČIŪTÉ 1966). The study of Belanger (1976) covered a shorter period of time, from 11 September to 26 October, at weekly intervals, but showed the highest abundance of Oribatida in the last sampling session. In contrast, DonaldSon (1996) did not find any significant seasonal changes, neither in mite density nor in species diversity, but her sampling was done earlier, on 21 April, 9 June, and 30 July. Also in the present study the abundance of Oribatida was similar in spring and summer, while in late autumn it was almost twice as high.

DonALDSON (1996) noticed significant seasonal differences in mites from the genus Limnozetes; L. foveolatus and L. ciliatus were the most abundant in early spring, while other species in early or late summer. Also in this study Limnozetes spp. showed different seasonal patterns; the density of L.foveolatus and L. ciliatus was the highest in autumn, while L. lustrum in summer, and L. rugosus in spring. A high density of $L$. ciliatus in autumn can be easily explained by its high reproduction in summer. The fecundity of this species was much higher at $25^{\circ} \mathrm{C}$ than at $20^{\circ} \mathrm{C}$, and the adults collected from the field showed seasonal differences in their fecundity, with the highest value in summer and the lowest in autumn (KURIKI 2008). Similar patterns of seasonal dynamics have been noticed for 2 dominant oribatid species in a mire in Japan, Trhypochthoniellus brevisetus and Limnozetes ciliatus, with a peak in spring to early autumn, and a decrease during colder seasons (KURIKI 2008).

Also some members of Malaconothroidea had their maximum abundance in different seasons; Trhypochthoniellus longisetus and Trhypochthonius nigricans were the most abundant in summer, Trimalaconothrus maior in spring, and T. foveolatus in autumn. Different seasonal dynamics might be explained as a strategy to facilitate the coexistence of species that have similar ecological requirements (SENICZAK \& SENICZAK 2006). 


\section{CONCLUSIONS}

The density of Oribatida was significantly higher in autumn than in spring, while species diversity did not show any seasonal variation. In all seasons Limnozetes foveolatus dominated, followed by L. ciliatus; relatively abundant were L. lustrum, Trhypochthoniellus longisetus, Trhypochthonius nigricans, and Trimalaconothrus foveolatus. The percentage of juvenile stages was generally low but higher in summer $(22 \%)$, which was connected with the reproductive season of the dominant species.

Acknowledgements: I am very grateful to Prof. dr. hab. S. Seniczak (Department of Ecology, University of Technology and Life Sciences, Bydgoszcz, Poland) for his critical comments on this manuscript and many valuable suggestions.

\section{REFERENCES}

Behan-Pelletier V. M. 1989. Limnozetes (Acari: Oribatida: Limnozetidae) of northeastern North America. Can. Ent. 121: 453-506.

Belanger S. D. 1976. The microarthropod community of Sphagnum moss with emphasis on the Oribatei. M.Sc. thesis. State University of New York, Syracuse, N.Y., USA.

BorCARD D. 1997. Oribatid mites in peat-bog remnants of the Swiss Jura mountains. Abh. Ber. Naturkundemus. Görlitz 69: 19-23.

BoIŃSKi M., BoIŃSKA U. 2003. Plan ochrony Rezerwatu Przyrody „Jeziorka Kozie” na lata 20032033 [Plan of protection of the nature reserve 'Jeziorka Kozie' for the years 2003-2033]. 'Oikos' Inwerntaryzacja i Waloryzacja Przyrodnicza, Projekty i Plany Ochrony, Toruń (in Polish).

Donaldson G. M. 1996. Oribatida (Acari) associated with three species of Sphagnum at Spruce Hole Bog, New Hampshire, U.S.A. Can. J. Zool. 74: 1713-1720.

EITMINAVIČIŪTĖ I. 1966. Oribatidy beregov zabolochennykh ozer (1. Nizinnoje boloto) [Oribatida of bog lakes shores (1. Fens)]. Lietuvos TSR Mokslų akademijos darbai, Serija C 1: 53-62 (in Russian).

Kenl C. 1997. Ecology of Malaconothroidea (Acari, Oribatida) in Northeast German mires. Abh. Ber. Naturkundemus. Görlitz 69: 11-18.

KURIKI G. 1993. Reproductive process and developmental rate of Trhypochthoniellus setosus Willmann (Oribatida). J. Acarol. Soc. Jpn. 2: 7-13.

KURIKI G. 1995. Life cycle of Trhypochthoniellus setosus Willmann (Acari: Trhypochthoniidae) in a Sphagnum moor at Yachidaira, Northeast Japan. J. Acarol. Soc. Jpn. 4: 113-122.

KURIKI G. 1996. On the faecal pellets deposition of Trhypochthoniellus setosus Willmann (Oribatida: Trhypochthoniidae). J. Acarol. Soc. Jpn. 5: 27-34.

KuRIKI G. 2008. The life cycle of Limnozetes ciliatus (Schrank, 1803) (Acari: Oribatida). J. Acarol. Soc. Jpn. 17: 75-85.

ŁoMNICKI A. 2010. Wprowadzenie do statystyki dla przyrodników [Introduction to statistics for the biologists]. PWN, Warszawa (in Polish).

Niedbala W., Olszanowski Z. 2008. Roztocze (Acari) [Mites (Acari)]. In: Fauna of Poland. Characteristics and checklist of species (Bogdanowicz W., Chudzicka E., Pilipuk I., Skibińska E., Eds), 3, pp. 11-14, Muzeum i Instytut Zoologii PAN, Warszawa (in Polish).

Odum E. P. 1982. Podstawy ekologii [Fundamentals of ecology]. PWRiL, Warszawa (in Polish). 
Olszanowski Z., Rajski A., Niedbata W. 1996. Katalog Fauny Polski. Roztocze (Acari), mechowce (Oribatida) [Catalog of Polish fauna. Mites (Acari), moss mites (Oribatida)]. Sorus, Poznań, Poland, 34(9): 1-243 (in Polish).

Peus F. 1932. Die Tierwelt der Moore unter besonderer Berücksichtigung der europäischen Hochmoore [The world of animals of mires with a special attention to European raised bogs]. Handbuch der Moorkunde 3, Berlin (in German).

Popp E. 1962. Semiaquatile Lebensräume (Bülten) in Hoch- und Niedermooren. II. Die Milbenfauna [Semi-aquatic habitats (hummocks) of raised bogs and fens. (2nd Part. The mite fauna)]. Int. Rev. Ges. Hydrobiol. 47: 533-579 (in German).

RAJSKI A. 1961. Faunistic-ecological investigations on moss mites (Acari, Oribatei) in several plant associations. I. Ecology. Bull. Soc. Amis. Sc. Lettr. Poznań, ser. B. 25(2): 123-283.

Schatz H., Behan-Pelletier V. M. 2008. Global diversity of oribatids (Oribatida: Acari: Arachnida). Hydrobiologia 595: 323-328.

Seniczak S., Bukowski G., Seniczak A., Bunowska H. 2006a. The soil Oribatida (Acari) of the ecotones between the Scots pine forest and lakes in the National Park Bory Tucholskie. Biol. Lett. 43: 221-225.

Seniczak A., Seniczak S., Nowicka A. 2006b. Roztocze (Acari) strefy brzegowej dwóch jezior śródleśnych o różnej jakości wody, w Borach Tucholskich [The mites (Acari) of the water edge of two forest ponds with different water quality in the Tuchola Forest]. Zootechnika 36 : 31-38 (in Polish).

Seniczak S., SenicZak A. 2006. Oribatid mites (Acari) of some habitats on Rhodes Island (Greece). Biol. Lett. 43: 215-219.

Seniczak S., SenicZaK A. 2009. Morphology of some species of Limnozetes Hull, 1916 (Acari: Oribatida: Limnozetidae), and keys to the larvae and nymphs. Ann. Zool. 59 (3): 387-396.

SkubąA P. 2004. Colonization and development of oribatid mite communities (Acari: Oribatida) on post-industrial dumps. Wyd. Uniwersytetu Śląskiego, Katowice.

SuBíAs L. S. 2004. Systematic, synonymic and biogeographical check- list of the world's oribatid mites (Acariformes, Oribatida) (1758-2002). Graellsia 60: 3-305.

TARras-WAhlberg N. 1961. The Oribatei of a central Swedish bog and their environment. Oikos Suppl. 4: 1-54.

Walter D. E., Norton R. A. 1984. Body size distribution in sympatric oribatid mites (Acari: Sarcoptiformes) from California pine litter. Pedobiologia 27: 99-106.

Weigmann G. 2006. Hornmilben (Oribatida). [Oribatid mites (Oribatida)]. In: Die Tierwelt Deutschland und der angrenzenden Meeresteile (Dahl F., Ed.), 76. Teil. Goecke \& Evers, Keltern (in German). 